\title{
Association between Dietary Glycemic Index and Excess Weight in Pregnant Women in the First Trimester of Pregnancy
}

\section{Associação entre o índice glicêmico dietético e o excesso de peso em gestantes no primeiro trimestre de gestação}

\author{
Thais Helena de Pontes Ellery ${ }^{1}$ Helena Alves de Carvalho Sampaio ${ }^{1}$ Antônio Augusto Ferreira Carioca ${ }^{2}$ \\ Bruna Yhang da Costa Silva ${ }^{1,3}$ Júlio Augusto Gurgel Alves ${ }^{4}$ Fabrício Da Silva Costa 5,6 \\ Edward Araujo Júnior ${ }^{7,8}$ Maria Luísa Pereira de Melo ${ }^{1}$
}

${ }^{1}$ Group of Research in Nutrition and Chronic Diseases, Universidade Estadual do Ceará, Fortaleza, CE, Brazil

${ }^{2}$ Department of Nutrition, Universidade de Fortaleza, Fortaleza, Ceará, Brazil

${ }^{3}$ Department of Nutrition, Instituto Federal de Educação, Ciência e Address for correspondence Edward Araujo Júnior, PhD, Escola Paulista de Medicina, Universidade Federal de São Paulo, Rua Botucatu, 720, 04023-062, Vila Clementino, São Paulo, SP, Brazil (e-mail: araujojred@terra.com.br).

Tecnologia do Ceará, Limoeiro do Norte, CE, Brazil

${ }^{4}$ Department of Maternal and Child, Universidade Federal do Ceará, Fortaleza, Ceará, Brazil

${ }^{5}$ Department of Obstetrics and Gynecology, Ribeirão Preto Medical School, Universidade de São Paulo, Ribeirão Preto, SP, Brazil

${ }^{6}$ Department of Obstetrics and Gynecology, Monash University, Faculty of Medicine, Nursing and Health Sciences, Clayton, Victoria, Australia

${ }^{7}$ Department of Obstetrics, Paulista School of Medicine, Universidade Federal de São Paulo, São Paulo, SP, Brazil

8 Medicine Course, Universidade Municipal de São Caetano do Sul, São Paulo-SP, Brazil

Rev Bras Ginecol Obstet 2019;41:4-10.

\begin{abstract}
Objective To assess the association between dietary glycemic index $(\mathrm{Gl})$ and excess weight in pregnant women in the first trimester of pregnancy.

Methods A cross-sectional study in a sample of 217 pregnant women was conducted at the maternal-fetal outpatient clinic of the Hospital Geral de Fortaleza, Fortaleza, state of Ceará, Brazil, for routine ultrasound examinations in the period between 11 and 13 weeks +6 days of gestation. Weight and height were measured and the gestational body mass index (BMI) was calculated. The women were questioned about their usual body weight prior to the gestation, considering the prepregnancy weight. The dietary

\section{Keywords}

- pregnancy

- glycemic index

- glycemic load

- excess weight $\mathrm{Gl}$ and the glycemic load (GL) of their diets were calculated and split into tertiles. Analysis of variance (ANOVA) or Kruskal-Walls and chi-squared $\left(x^{2}\right)$ statistical tests were employed. A crude logistic regression model and a model adjusted for confounding variables known to influence biological outcomes were constructed. A p-value $<0.05$ was considered significant for all tests employed.
\end{abstract}

(D) Edward Araujo Júnior's ORCID is https://orcid.org/0000-0002-6145-

2532.

received

March 19, 2018

accepted

October 10, 2018

published online

December 12, 2018
DOI https://doi.org/

$10.1055 / \mathrm{s}-0038-1676096$. ISSN 0100-7203.
Copyright $\odot 2019$ by Thieme Revinter

Publicações Ltda, Rio de Janeiro, Brazil

License terms

(c) (P) 


\section{Resumo}

\author{
Palavras-chave \\ - gestação \\ - índice glicêmico \\ - carga glicêmica \\ - excesso de peso
}

Results The sample group presented a high percentage of prepregnancy and gestational overweight (39.7\% and $40.1 \%$, respectively). In the tertile with the higher GIvalue, there was a lower dietary intake of total fibers $(p=0.005)$ and of soluble fibers $(p=0.008)$. In the third tertile, the dietary $\mathrm{Gl}$ was associated with overweight in pregnant women in the first trimester of gestation, both in the crude model and in the model adjusted for age, total energy intake, and saturated fatty acids. However, this association was not observed in relation to the GL.

Conclusion A high dietary $\mathrm{Gl}$ was associated with excess weight in women in the first trimester of pregnancy.

Objetivo Avaliar a associação entre índice glicêmico (IG) dietético e presença de excesso de peso em gestantes no primeiro trimestre de gestação.

Métodos Estudo transversal realizado com 217 gestantes atendidas no Ambulatório de Medicina Materno-Fetal do Hospital Geral de Fortaleza, Fortaleza, CE, para realização de exames ultrassonográficos de rotina no período entre 11 e 13 semanas e 6 dias de gestação. Peso e altura foram obtidos para o cálculo do índice de massa corporal (IMC) gestacional. As mulheres foram questionadas quanto ao peso corporal habitual anterior à gestação, considerado o peso pré-gestacional. O IG e a carga glicêmica (CG) das suas dietas foram calculados e divididos em tercis. As associações foram investigadas por análise de variância (ANOVA, na sigla em inglês) ou pelos testes Kruskal-Walls e qui-quadrado $\left(x^{2}\right)$.

Resultados O grupo tinha alto percentual de excesso de peso pré-gestacional $(39,7 \%)$ e gestacional $(40,1 \%)$. Houve menor consumo de fibras totais $(p=0,005)$ e fibras insolúveis $(p=0,008)$ no tercil de maior valor de IG. No terceiro tercil, o IG da dieta foi associado ao excesso de peso das mulheres no primeiro trimestre de gestação, tanto no modelo bruto como no modelo ajustado para idade, consumo total de energia e de ácidos graxos saturados. No entanto, não se observou esta associação em relação à CG. Conclusão O alto IG da dieta consumida foi associado ao excesso de peso das mulheres no primeiro trimestre da gestação.

\section{Introduction}

Gestational weight gain is the focus of several studies, ${ }^{1-5}$ as a result of the worldwide epidemic of obesity ${ }^{1-3}$ and its importance in gestational outcomes. ${ }^{4,5}$ Excessive gestational weight gain has been associated with increased risk of large infants for the gestational age (GA), preeclampsia, gestational diabetes, cephalopelvic disproportion, trauma, asphyxia, and perinatal death. ${ }^{4,5}$ Excessive gestational weight gain is associated with postpartum weight retention. $^{3}$

In the last few years, the relevance of the dietary glycemic index (GI) for the development of obesity has been controversially debated. ${ }^{6-8}$ The GI is considered an important determinant of fasting glucose tolerance and of postprandial glycemic response. ${ }^{7-9}$ Mechanisms linking the habitual consumption of high-GI foods to body composition include reduced satiety signaling, enhanced carbohydrate oxidation, and decreased fat oxidation in response to habitual postprandial glycemia and insulinemia. 8,9

The GI quantifies the glycemic variations in response to the dietary carbohydrate consumption, and is defined as the area under the glucose response curve after the intake of
$50 \mathrm{~g}$ of carbohydrates of a test-food, expressed as a percentage response to the same quantity of carbohydrate of a standard food, measured in the same individual. ${ }^{10}$ The glycemic load (GL) is a measure derived from the quantity and quality (GI) of dietary carbohydrates. ${ }^{11}$

High-GI and/or high-GL diets are independently associated with the development and with the progression of chronic diseases, particularly those associated with insulin resistance. 6,11 The hypothesis that there is an association between overall dietary GI, GL, and disease risk have been inconsistent with this hypothesis. ${ }^{12,13}$

Therefore, given the importance of the diet to the nutritional status and health of pregnant women, the objective of the present study was to evaluate the association of dietary GI and GL during pregnancy with excess weight (overweight and obesity) in women at prepregnancy and during the first trimester of gestation.

\section{Methods}

A cross-sectional study, part of a larger prospective cohort entitled "Prediction of preeclampsia using the triple vascular 
test" was conducted at the maternal-fetal outpatient clinic of the Hospital Geral de Fortaleza, Fortaleza, state of Ceará, Brazil. The study was approved by the Local Ethics Committee (reference number 050309/09). All of the participants of the present study were informed of the purpose of the study and of all the potential risks involved before signing a written consent form.

The sample comprised 217 pregnant women that underwent routine ultrasound scans at between 11 and 13 weeks +6 days of gestation. Weight and height were measured during pregnancy using a Marte digital anthropometric scale (Marte Científica, São Paulo, SP, Brazil), with a capacity of $200 \mathrm{~kg}$ and $2 \mathrm{~m}$, with a sensitivity of $50 \mathrm{~g}$ and of $0.50 \mathrm{~cm}$, respectively. The women were questioned about their usual body weight prior to the gestation, considering the prepregnancy weight. Their body mass index (BMI) was calculated as their weight in kilograms divided by their height in meters squared $\left(\mathrm{kg} / \mathrm{m}^{2}\right)$. The prepregnancy BMI was classified according to the World Health Organization (WHO) ${ }^{14}$ criteria as underweight $\left(<18.5 \mathrm{~kg} / \mathrm{m}^{2}\right)$, normal $\left(18.5-24.9 \mathrm{~kg} / \mathrm{m}^{2}\right)$, overweight $\left(25.0-29.9 \mathrm{~kg} / \mathrm{m}^{2}\right)$ and obese $\left(\geq 30 \mathrm{~kg} / \mathrm{m}^{2}\right)$. The gestational BMI was classified using the table of Atalah et al. ${ }^{15}$ Overweight or obese women were grouped together into a category named excess weight.

Dietary intake data was collected through interviews that were applied two the 24 hours dietary recall (24hDR) during 2 non-consecutive days, including one weekend day. The pregnant women informed their daily food intake from the previous 24 hours in household measures and, subsequently, we converted them into grams. ${ }^{16}$ Dietary data were input to the DietWin Profissional 2.0 software (dietWin, Porto Alegre, RS, Brazil), which calculated the nutritional composition of the diets, along with the total daily energy intake in kilocalories (Kcal). The nutrients consumed were adjusted for energy using the residual method ${ }^{17}$ and were expressed in $\mathrm{g} /$ 1,000 Kcal.

Based on the information available for the chemical composition of the diets, the GI was determined using the table of Brand-Miller et al. ${ }^{18,19}$ For foods whose GIs were not listed in the tables, the value was estimated based on foods with similar characteristics and carbohydrate levels. The daily GI was calculated by multiplying the GI of each food (IGf) by the proportion of glycemic carbohydrate in the food item ( $\operatorname{HCOg} f=\operatorname{HCO} f$ - total fiber of food) regarding the amount of daily glycemic carbohydrate, and summing the resultant values (daily GI $\left.=\sum(\operatorname{GI} f \times \operatorname{HCOg} f) / \sum \operatorname{HCOg} f\right)$. The daily GL was determined by adding the glycemic carbohydrate of each food, in grams, multiplied by its individual GI, and dividing it by 100 (daily GL $\left.=\sum(\mathrm{GI} f \times \operatorname{HCOg} f) / 100\right){ }^{20}$ The daily GI and GL of each of the two recalls were calculated, and an arithmetic mean of daily GI and GL for each individual was obtained. The usual intake of GI and GL was estimated by the multiple source method (MSM) to correct for interpersonal variability. ${ }^{21}$ The mean values adjusted by the MSM were split into tertiles.

In addition, the presence of under-reporting of dietary intake was analyzed. To this end, the basal metabolic rate (BMR) was estimated using the formulas recommended by the Food and Agriculture Organization (FAO)/WHO, ${ }^{22}$ and the total energy intake/BMR ratio was calculated. Values $<1.5$, which is the reference cutoff point, were considered indicative of under-reporting. ${ }^{23}$

The values for dietary intake and anthropometric variables were split into the GI tertiles. Analysis of variance (ANOVA) or the Kruskal-Walls and chi-squared $\left(\mathrm{X}^{2}\right)$ statistical tests were employed. A crude logistic regression model and a model adjusted for confounding variables known to influence biological outcomes were constructed. A $p$-value $<0.05$ was considered significant for all statistical tests used. The IBM SPSS for Windows, Version 20.0 (IBM Corp., Armonk, NY, USA) was used for all analyses.

\section{Results}

The majority (77.9\%) of the participants of the present study were between 19 and 34 years old, and most patients (67.7\%) were married or living with a partner. The distribution of the women according to their reported race was predominantly mixed (71.4\%) and white (24.4\%). The anthropometric data from the pregnant women are presented in - Table 1. The mean prepregnancy BMI of the population studied was $24.5 \mathrm{~kg} / \mathrm{m}^{2}( \pm 4.4)$. The prepregnancy BMIs showed that a high percentage (39.7\%) of the patients had excess weight (overweight and obese). The gestational BMIs (first trimester of gestation) revealed that $40.1 \%$ of the women had excess weight. The mean BMI of the population increased to $25.1 \mathrm{~kg} /$ $\mathrm{m}^{2}( \pm 4.4)$. Weight gain occurred in most of the women (71.9\%), with a mean weight increase of $3.1 \mathrm{~kg}( \pm 2.5)$.

The relationship between sociodemographic profile, GA, BMI, and food consumption with the GI tertiles are shown in - Table 2. There was a significant difference in the consumption of total $(p=0.005)$ and insoluble fibers $(p=0.008)$, with a lower intake of this nutrient in the highest GI tertile. The GL varied between the three tertiles $(p=0.002)$ without a specific pattern, but following the variation of carbohydrates, even though the latter did not give a difference between the tertiles.

Table 1 Anthropometric assessment at prepregnancy and during the first trimester of pregnancy

\begin{tabular}{|l|l|}
\hline Variable & $n(\%)$ \\
\hline *Prepregnancy nutritional diagnosis \\
\hline Underweight & $9(4.1)$ \\
\hline Normal weight & $122(56.2)$ \\
\hline Excess weight & $86(39.7)$ \\
\hline **Nutritional diagnosis during pregnancy \\
\hline Underweight & $34(15.7)$ \\
\hline Normal weight & $96(44.2)$ \\
\hline Excess weight & $87(40.1)$ \\
\hline Total & $217(100.0)$ \\
\hline
\end{tabular}

Source: ${ }^{*}$ Rasmussen et al (2009) ${ }^{14}$ and ${ }^{* *}$ Atalah et al (1997). ${ }^{15}$ 
Table 2 Distribution of gestational and dietary intake characteristics according to the glycemic index

\begin{tabular}{|c|c|c|c|c|}
\hline \multirow[t]{2}{*}{ Variables } & \multicolumn{3}{|l|}{ GI } & \multirow[t]{2}{*}{ p-value } \\
\hline & $54.1-57.4(n=72)$ & $57.5-58.2(n=73)$ & $58.3-60.5(n=72)$ & \\
\hline \multicolumn{5}{|l|}{ Dietary intake } \\
\hline Energy, Kcal & $1,950.7(553.0)$ & $1,963.7(629.5)$ & $1,743.6(682.2)$ & 0.061 \\
\hline Protein, g/1000 Kcal & $44.7(9.9)$ & $41.9(12.2)$ & $46.1(12.2)$ & 0.093 \\
\hline Carbohydrate, g/1000 Kcal & $128.8(19.4)$ & $129.1(20.4)$ & $123.2(20.9)$ & 0.150 \\
\hline Dietary fiber, $g$ & $20.0(10.5)$ & $19.7(9.8)$ & $15.1(6.3)$ & $0.005^{*}$ \\
\hline Soluble fiber, $\mathrm{g}$ & $6.9(4.0)$ & $6.4(3.3)$ & $5.4(2.7)$ & 0.071 \\
\hline Insoluble fiber, $\mathrm{g}$ & $9.4(5.9)$ & $9.7(6.6)$ & $7.0(3.7)$ & $0.008^{*}$ \\
\hline Lipids, g/1,000 Kcal & $33.8(6.7)$ & $34.8(7.3)$ & $35.4(8.7)$ & 0.435 \\
\hline SFA, g/1,000 Kcal & $10.8(3.2)$ & $9.8(3.0)$ & $9.8(3.1)$ & 0.065 \\
\hline PFA, g/1,000 Kcal & $6.4(3.7)$ & $6.6(3.4)$ & $7.2(3.7)$ & $0.250^{\#}$ \\
\hline MFA, g/1,000 Kcal & $8.8(2.5)$ & $8.6(3.0)$ & $9.3(3.4)$ & 0.354 \\
\hline Glycemic load & $141.3(26.1)$ & $143.7(38.4)$ & $124.5(32.2)$ & $0.002^{*}$ \\
\hline Energy under-reporting, \% & $44(61.1)$ & $49(67.1)$ & $53(73.6)$ & 0.279 \\
\hline \multicolumn{5}{|l|}{ Socioeconomic profile } \\
\hline Age, years old & $27.6(6.3)$ & $27.3(7.2)$ & $26.8(6.9)$ & 0.284 \\
\hline Marital Status, married (\%) & $45(62.5)$ & $55(75.3)$ & $47(65.3)$ & 0.311 \\
\hline \multicolumn{5}{|l|}{ Nutritional status } \\
\hline Gestational age, weeks & $12.6(0.9)$ & $12.8(0.8)$ & $12.6(0.9)$ & 0.307 \\
\hline Prepregnancy BMI, ${ }^{1} \mathrm{~kg} / \mathrm{m}^{2}$ & $24.5(3.7)$ & $25.2(4.1)$ & $25.0(4.6)$ & 0.199 \\
\hline Gestational $\mathrm{BMI},{ }^{2} \mathrm{~kg} / \mathrm{m}^{2}$ & $24.9(3.2)$ & $25.5(4.2)$ & $25.8(4.6)$ & 0.204 \\
\hline Pre-BMI, ${ }^{1}$ excess weight (\%) & $26(36.1)$ & $30(41.1)$ & $39(54.2)$ & 0.078 \\
\hline${ }^{2}$ Gestational BMI, excess weight (\%) & $36(50.6)$ & $37(50.7)$ & $48(66.7)$ & 0.074 \\
\hline
\end{tabular}

Abbreviations: BMI, body mass index; g, grams; GI, glycemic index; MFA, monounsaturated fatty acids; PFA, polyunsaturated fatty acids; SFA, saturated fatty acids.

Source: ${ }^{\#}$ Rasmussen et al (2009) ${ }^{14}$ and ${ }^{\# \#}$ Atalah et al (1997). ${ }^{15}$

*ANOVA Test: $p<0.05$.

${ }^{*}$ Kruskal-Wallis and $\mathrm{X}^{2}: p<0.05$.

All of the dietary intake variables and gestational characteristics were tested according to the GI and GL tertiles. Logistic regression models were constructed showing that the high GI values in the third tertile were associated with excess weight (overweight and obesity) of the pregnant women in the first trimester in both the crude model and in the model adjusted for age, total energy intake, saturated fatty acids, and under-reporting. This association was not observed for the GL (-Table 3).

\section{Discussion}

The results of the present study revealed a high rate of excess weight (overweight and obesity) before pregnancy, showing the need for continuous monitoring of weight and food consumption. ${ }^{3,15}$ Adequate weight gain and nutrient intake are fundamental for the gestational period, preventing complications in pregnancy outcomes. ${ }^{4,5,24}$ Prepregnancy excess weight is a risk factor for overweight and obesity during pregnancy. Pregnant women gain weight during this period but beginning the pregnancy with excess weight can lead to an increase in body mass that can affect negatively the health of both the mother and the newborn. ${ }^{2,25}$

Excess weight in the first trimester of pregnancy was found in $40.1 \%$ of the women. This group may have included women with excess weight before pregnancy that continued to gain weight. Excessive gestational weight gain has been associated with an increased risk of large infants for the $\mathrm{GA},{ }^{24,26}$ preeclampsia, gestational diabetes, cephalopelvic disproportion, trauma, asphyxia, and perinatal death. ${ }^{4,5}$

Excessive weight gain can lead to an increased risk of postpartum weight retention, influencing a potential obesity that may persist or worsen during the lifetime of the woman. ${ }^{1,27}$ Mattar et al ${ }^{1}$ observed that $\sim 50 \%$ of the overweight or obese women had a higher than recommended weight gain, and that $>70 \%$ of them maintained the excessive weight up to 12 months postpartum, and $30 \%$ had a retention of $\geq 10 \mathrm{~kg}$.

Our results showed a greater risk of overweight in individuals who consumed diets with a higher GI. Sampaio et al ${ }^{6}$ observed the consumption of foods with a high or moderate 
8 Association between Dietary Glycemic Index and Excess Weight in Pregnant Women Ellery et al.

Table 3 Odds ratio of gestacional body mass index according the tertiles of glycemic index and glycemic load adjusted by the multiple source method

\begin{tabular}{|c|c|c|c|}
\hline & \multicolumn{3}{|c|}{ Gestational BMI* (with and without excess weight) } \\
\hline & Crude model & Model $1^{* *}$ & Model $2^{* * *}$ \\
\hline & OR $(95 \% \mathrm{Cl})$ & OR $(95 \% \mathrm{Cl})$ & OR $(95 \% \mathrm{Cl})$ \\
\hline \multicolumn{4}{|l|}{ GI MSM } \\
\hline $1^{\text {st }}$ tertile $(54.1-57.4)$ & 1.00 & 1.00 & 1.00 \\
\hline $2^{\text {nd }}$ tertile $(57.5-58.2)$ & $1.028(0.536-1.971)$ & $0.992(0.504-1.955)$ & $0.993(0.494-1.996)$ \\
\hline $3^{\text {rd }}$ tertile $(58.3-60.5)$ & $2.000(1.020-3.922)$ & $1.988(0.981-4.029)$ & $2.204(1.064-4.567)$ \\
\hline$p$-value & 0.045 & 0.059 & 0.034 \\
\hline \multicolumn{4}{|l|}{ GL MSM } \\
\hline $1^{\text {st }}$ tertile $(52.9-119.7)$ & 1.00 & 1.00 & 1.00 \\
\hline $2^{\text {nd }}$ tertile (120.9-146.1) & $1.147(0.592-2.223)$ & $1.216(0.566-2.611)$ & $1.201(0.552-2.614)$ \\
\hline $3^{\text {rd }}$ tertile $(148.4-307.0)$ & $0.756(0.392-1.458)$ & $1.149(0.446-2.961)$ & $1.645(0.583-4.644)$ \\
\hline$p$-value & 0.402 & 0.764 & 0.354 \\
\hline
\end{tabular}

Abbreviations: BMI, body mass index; $\mathrm{Cl}$, confidence interval; Gl, glycemic index; GL, glycemic load; MSM, multiple source method; OR, odds ratio. ${ }^{*}$ First trimester; ${ }^{* *}$ Adjusted for age (tertile) and total energy intake (tertile); ${ }^{* * *}$ Adjusted for age (tertile), total energy intake (tertile), saturated fatty acids (tertiles), and under-reporting (yes or no).

GI in $78.7 \%$ of an obese group, highlighting a high percentage of individuals who consumed diets with inadequate GI at breakfast (82.9\%), at afternoon snacks (60.0\%), and at dinner (64.6\%).

The GI quantifies the glycemic variations in response to the dietary carbohydrate consumption. When diets with high GI are consumed, a glycemic increase occurs due to the high level of glucose, leading to hyperinsulinemia. ${ }^{28}$ Different sources of carbohydrates have varying absorption rates, and their effects on plasma concentrations of glucose and insulin vary accordingly. ${ }^{29,30}$ In the present study, both the intake of total fiber as well as of the insoluble fiber declined by the tertile. Diets containing a higher level of fiber retard the absorption of glucose by the organism, avoiding a rapid increase in blood glucose and reducing the release of insulin by the pancreas. ${ }^{7,30}$

Postprandial glycemia is modulated mainly by the speed of release of carbohydrates derived from the diet into the bloodstream after meals, by the clearance time of the carbohydrates through insulin secretion, and by peripheral tissue sensitivity to the action of this hormone. ${ }^{20,29}$ Thus, the type and amount of dietary carbohydrates are key factors that influence the glycemic response. ${ }^{30,31}$ Studies have shown that pregnant women receiving advice and encouragement to consume a low-GI diet have longer gestational periods, ${ }^{32,33}$ as well as fewer preterm births, although no effects of these diets on infant birth weight have been found in groups at risk of macrosomia. ${ }^{33}$

Another aspect to consider is the GL, which is calculated by multiplying the GI of foods by their glycemic carbohydrate content and reflects directly the quantity and quality of dietary carbohydrates. ${ }^{7,10}$ The GL is one of the most representative characteristics of the overall diet because it indicates the dietary fiber intake. ${ }^{9,10}$ No difference was observed among the GL values in the GI tertiles, probably because the
GL quantifies the total effect of a given amount of carbohydrate on plasma glucose, representing the GI product of a food by its available carbohydrate content. ${ }^{7}$ The GL can provide a better reflection of the glycemic response of a specific food than the GI. The glycemic effect of foods varies with the composition of the food and with the methods of preparation. $^{7,20}$ In addition, under-reporting was found in $53 \%$ of the pregnant women, which directly impacts the GL values. Usually, women with excess weight tend to not fully disclose their food intake for several reasons, including fear of exposing their poor eating habits. ${ }^{34}$

The level of GI necessary to affect body composition remains unclear. Further elucidation of the mechanisms associated with the potential benefits of consuming carbohydrates, as measured by GI values, is essential before introducing this as a strategy for controlling obesity and its comorbidities, particularly during pregnancy, when weight gain can be expected. Moses et $\mathrm{al}^{32}$ found no significant differences in fetal and obstetric outcomes between subjects who followed a low-GI diet versus a higher-GI diet. A randomized controlled trial ${ }^{35}$ reported no difference in birth weight of newborns of mothers consuming a low-GL diet, whereas the gestational period was 10 days longer in the same group, suggesting that this type of diet may be an important factor for preventing prematurity. A meta-analysis that assessed 7 maternal and 11 newborn outcomes observed that low-GI diets may have beneficial effects on maternal outcomes for those at risk of developing high glucose levels, without causing adverse effects on newborn outcomes. $^{36}$

\section{Conclusion}

Based in the results of the present study, it can be concluded that high-GI diets were associated with excess weight in pregnant women in the first trimester of gestation. 
Therefore, individualized nutritional consultations are recommended in this group to promote dietary improvements.

\section{Contributors}

Ellery T. H. P., Sampaio H. A. C., Carioca A. A. F., Silva B. Y. C., Alves J. A. G., Costa F. S., Araujo Júnior E. and Melo M. L. P. contributed with the project, the interpretation of data, the writing of the article, the critical review of the intellectual content, and with the final approval of the version to be published.

\section{Conflicts of Interest}

The authors have no conflicts of interest to declare.

\section{Acknowledgments}

The authors are grateful for the support of Coordenação de Aperfeiçoamento de Pessoal de Nível Superior (CAPES), through the scolarship during the master's degree, to the pregnant women and to the General Hospital of Fortaleza.

\section{References}

1 Mattar R, Torloni MR, Betrán AP, Merialdi M. [Obesity and pregnancy]. Rev Bras Ginecol Obstet 2009;31(03):107-110 Doi: 10.1590/S0100-72032009000300001

2 Carvalhaes MA, Gomes CdeB, Malta MB, Papini SJ, Parada CM. [Prepregnancy overweight is associated with excessive weight gain during pregnancy]. Rev Bras Ginecol Obstet 2013;35(11): 523-529 Doi: 10.1590/S0100-72032013001100008

3 Nast M, de Oliveira A, Rauber F, Vitolo MR. [Excessive gestational weight gain is risk factor for overweight among women]. Rev Bras Ginecol Obstet 2013;35(12):536-540 Doi: 10.1590/S010072032013001200002

4 Vernini JM, Moreli JB, Magalhães CG, Costa RAA, Rudge MVC, Calderon IMP. Maternal and fetal outcomes in pregnancies complicated by overweight and obesity. Reprod Health 2016;13(01): 100-119 Doi: 10.1186/s12978-016-0206-0

5 Khan MN, Rahman MM, Shariff AA, Rahman MM, Rahman MS, Rahman MA. Maternal undernutrition and excessive body weight and risk of birth and health outcomes. Arch Public Health 2017; 75:12 Doi: 10.1186/s13690-017-0181-0

6 Sampaio HA, Silva BY, Sabry MO, Almeida PC. Glycemic index and glycemic load of diets consumed by obese individuals. Rev Nutr 2007;20:615-624 Doi: 10.1590/S1415-52732007000600004

7 Augustin LS, Kendall CW, Jenkins DJ, et al. Glycemic index, glycemic load and glycemic response: An International Scientific Consensus Summit from the International Carbohydrate Quality Consortium (ICQC). Nutr Metab Cardiovasc Dis 2015;25(09): 795-815 Doi: 10.1016/j.numecd.2015.05.005

8 Guttierres APM, Alfenas RdeC. [Effects of glycemic index on energy balance]. Arq Bras Endocrinol Metabol 2007;51(03): 382-388 Doi: 10.1590/S0004-27302007000300005

9 Juanola-Falgarona M, Salas-Salvadó J, Buil-Cosiales P, et al; PREvencion con Dleta MEDiterranea Study Investigators. Dietary glycemic index and glycemic load are positively associated with risk of developing metabolic syndrome in middle-aged and elderly adults. J Am Geriatr Soc 2015;63(10):1991-2000 Doi: 10.1111 /jgs. 13668

10 Brand-Miller J, Wolever TMS, Colagiuri S, Foster-Powell K. The Glucose Revolution: the Authoritative Guide to the Glycemic Index-the Groundbreaking Medical Discovery. Boston, MA: Da Capo; 1999

11 Atkinson FS, Foster-Powell K, Brand-Miller JC. International tables of glycemic index and glycemic load values: 2008. Diabetes Care 2008;31(12):2281-2283 Doi: 10.2337/dc08-1239
12 Nadeau KJ, Anderson BJ, Berg EG, et al. Youth-onset type 2 diabetes consensus report: current status, challenges, and priorities. Diabetes Care 2016;39(09):1635-1642 Doi: 10.2337/dc161066

13 Giugliano D, Maiorino MI, Bellastella G, Esposito K. Comment on American Diabetes Association. Approaches to Glycemic Treatment. Sec. 7. In Standards of Medical Care in Diabetes-2016. Diabetes Care 2016;39(Suppl. 1):S52-S59. Diabetes Care 2016;39 (06):e86-e87 Doi: 10.2337/dc15-2829

14 Rasmussen KM, Yaktine AL. Institute of Medicine, National Research Council, Committee to Reexamine IOM Pregnancy Weight Guidelines. Weight Gain During Pregnancy: Reexamining the Guidelines. Washington, DC: National Academies Press; 2009

15 Atalah E, Castillo C, Castro R, Aldea A. [Proposal of a new standard for the nutritional assessment of pregnant women]. Rev Med Chil 1997;125(12):1429-1436

16 Pinheiro ABV, Lacerda EMA, Benzecry EH, Gomes MCS, Costa VM. Tabela para Avaliação de Consumo Alimentar em Medidas Caseiras. 5a ed. São Paulo, SP: Atheneu; 2008

17 Willett WC, Howe GR, Kushi LH. Adjustment for total energy intake in epidemiologic studies. Am J Clin Nutr 1997;65(4, Suppl) 1220S-1228S, discussion 1229S-1231S Doi: 10.1093/ajen/ 65.4.1220S

18 Brand-Miller J, Nantel G, Slama G, Lang V. Glycaemic Index and Health: the Quality of the Evidence. Paris: John Libbey Eurotex; 2001

19 Brand-Miller J, Foster-Powell K, Atkinson F. The Shopper's Guide to GI Values: The Authoritative Source of Glycemic Index Values for More Than 1,200 Foods. Boston, MA: Da Capo; 2015

20 Lau C, Faerch K, Glümer C, et al; Inter99 study. Dietary glycemic index, glycemic load, fiber, simple sugars, and insulin resistance: the Inter99 study. Diabetes Care 2005;28(06):1397-1403

21 Harttig U, Haubrock J, Knüppel S, Boeing H; EFCOVAL Consortium. The MSM program: web-based statistics package for estimating usual dietary intake using the Multiple Source Method. Eur J Clin Nutr 2011;65(Suppl 1):S87-S91 Doi: 10.1038/ejcn.2011.92

22 FAO/WHO. Human Energy Requirements: Report of a Joint FAO/ WHO/UNU Expert Consultation. Rome: Food and Agriculture Organization; 2004

23 Goldberg GR, Black AE, Jebb SA, et al. Critical evaluation of energy intake data using fundamental principles of energy physiology: 1 . Derivation of cut-off limits to identify under-recording. Eur J Clin Nutr 1991;45(12):569-581

24 Liu P, Xu L, Wang Y, et al. Association between perinatal outcomes and maternal pre-pregnancy body mass index. Obes Rev 2016;17 (11):1091-1102 Doi: 10.1111/obr.12455

25 Tovar A, Must A, Bermudez OI, Hyatt RR, Chasan-Taber L. The impact of gestational weight gain and diet on abnormal glucose tolerance during pregnancy in Hispanic women. Matern Child Health J 2009;13(04):520-530 Doi: 10.1007/s10995-008-0381-x

26 Knudsen VK, Heitmann BL, Halldorsson TI, Sørensen TI, Olsen SF. Maternal dietary glycaemic load during pregnancy and gestational weight gain, birth weight and postpartum weight retention: a study within the Danish National Birth Cohort. Br J Nutr 2013;109(08):1471-1478 Doi: 10.1017/S0007114512003443

27 Widen EM, Whyatt RM, Hoepner LA, et al. Excessive gestational weight gain is associated with long-term body fat and weight retention at $7 \mathrm{y}$ postpartum in African American and Dominican mothers with underweight, normal, and overweight prepregnancy BMI. Am J Clin Nutr 2015;102(06):1460-1467 Doi: 10.3945/ajcn.115.116939

28 Galgani J, Aguirre C, Díaz E. Acute effect of meal glycemic index and glycemic load on blood glucose and insulin responses in humans. Nutr J 2006;5:22 Doi: 10.1186/1475-2891-5-22

29 DeFronzo RA, Ferrannini E. Influence of plasma glucose and insulin concentration on plasma glucose clearance in man. Diabetes 1982;31(8 Pt 1):683-688 Doi: 10.2337/diab.31.8.683 
10 Association between Dietary Glycemic Index and Excess Weight in Pregnant Women Ellery et al.

30 Sheard NF, Clark NG, Brand-Miller JC, et al. Dietary carbohydrate (amount and type) in the prevention and management of diabetes: a statement by the american diabetes association. Diabetes Care 2004;27(09):2266-2271 Doi: 10.2337/diacare.27.9.2266

31 McGowan CA, McAuliffe FM. The influence of maternal glycaemia and dietary glycaemic index on pregnancy outcome in healthy mothers. Br J Nutr 2010;104(02):153-159 Doi: 10.1017/ S0007114510000425

32 Moses RG, Luebcke M, Davis WS, et al. Effect of a low-glycemicindex diet during pregnancy on obstetric outcomes. Am J Clin Nutr 2006;84(04):807-812 Doi: 10.1093/ajcn/84.4.807

33 Walsh JM, McGowan CA, Mahony R, Foley ME, McAuliffe FM. Low glycaemic index diet in pregnancy to prevent macrosomia (ROLO study): randomised control trial. BMJ 2012;345:e5605 Doi: 10.1136/bmj.e5605

34 Hill RJ, Davies PSW. The validity of self-reported energy intake as determined using the doubly labelled water technique. Br J Nutr 2001;85(04):415-430 Doi: 10.1079/BJN2000281

35 Rhodes ET, Pawlak DB, Takoudes TC, et al. Effects of a lowglycemic load diet in overweight and obese pregnant women: a pilot randomized controlled trial. Am J Clin Nutr 2010;92(06): 1306-1315 Doi: 10.3945/ajcn.2010.30130

36 Zhang R, Han S, Chen GC, et al. Effects of low-glycemic-index diets in pregnancy on maternal and newborn outcomes in pregnant women: a meta-analysis of randomized controlled trials. Eur J Nutr 2018;57(01):167-177 Doi: 10.1007/s00394-016-1306-x

Erratum: The ORCID ID of DOI: 10.1055/s-0038-1676096 has been changed from https://orcid.org/0000-00017510-0485 to https://orcid.org/0000-0002-6145-2532. 